Wahana Didaktika Vol. 16 No.3 September 2018 : 308-320

\title{
LAYANAN KONSELING KELOMPOK UNTUK MENGEMBANGKAN HUBUNGAN SOSIAL PESERTA DIDIK
}

\author{
Oleh: Hayu Stevani \\ (Dosen Universitas Indraprasta PGRI Jakarta) \\ Email: hayu.stevani@unindra.ac.id
}

\begin{abstract}
Abstrak
Penelitian ini berdasarkan fenomena peserta didik memiliki hubungan sosial yang kurang baik, dengan indikasi: suka menjelek-jelekan teman, memperolok-olok satu sama lain, meremehkan antar teman, menertawakan fisik, dan mengancam, sehingga munculnya kebiasaan yang tidak saling menghargai satu sama lain, Metode peneltian yang digunakan yaitu deskriptif kualitatif dengan menggunakan alat pengumpul data wawancara dan observasi. Sumber data dalam penelitian ini adalah, peserta didik kelas VIII SMP N 1 Lubuk Alung, koordinator dan guru BK, wali kelas serta guru bidang studi. Hasil dari penelitian adalah 1) hubungan sosial yang berorientasi pada peserta didik yang memiliki masalah hubungan sosial terlihat kurang baik, seperti: saat berinteraksi dengan teman sebaya sering membuat perilaku yang tidak disenangi oleh yang lain, 2) penyebab masalah hubungan sosial di antaranya faktor ekonomi, pengaruh teman sebaya dan pola asuh orang tua, 3) hasil pelaksanaan konseling kelompok oleh guru BK menggambarkan bahwa hubungan sosial peserta didik sudah mulai menjadi lebih baik dan peserta didik yang memiliki masalah hubungan sosial sudah dapat mengetahui dampak dari hubungan sosial yang tidak baik terhadap dirinya. Hasil penelitian ini diharapkan dapat menjadi acuan bagi guru BK dalam pelaksanakan konseling kelompok untuk mengembangkan hubungan sosial peserta didik, serta kepada para personil sekolah agar dapat selalu dapat mendukung serta membantu pelaksanaan layanan BK di sekolah.
\end{abstract}

Kata Kunci: Layanan Konseling Kelompok, Hubungan Sosial

\section{GROUP COUNSELING SERVICES TO DEVELOP SOSIAL RELATIONS LEARNERS}

\begin{abstract}
This research is based on the phenomenon of the learners have a less good sosial relationships, with indication of: love making friends, intensified each other, disparaging interracial friends, laugh at, and threatened, so the emergence of habits that do not appreciate each other mutually, peneltian Method used i.e. qualitative descriptive by using the tool collecting data through interviews and observations. The source of the data in this study is, learners class VIII SMP N 1 Bottom Alung, Coordinator and teacher of BK, homeroom teacher and field of study. The results of the research are 1) sosial relations oriented learners who have problems of sosial relations looks amateurish, like: when you interact with peers often makes the behavior that is not tolerated by the other, 2) the cause of
\end{abstract}


the problems of sosial relationships among these economic factors, the influence of peers and parents, parenting 3) results in the execution of counseling by teacher groups BK illustrate that sosial relations learners have already started to get better and learners sosial relations that has the problem been able to figure out the impact of the sosial relationships that are not good against him. The results of this research are expected to be a reference for teachers in pelaksanakan BK counseling groups to develop sosial relationships, learners as well as to the personnel of the school inorder to always be able to support and assist the implementation of services BK in school.

Keywords: Group Counseling Services, Sosial Relations

\section{A. PENDAhuluan}

Pendidikan merupakan upaya untuk membantu perkembangan peserta didik sebagai makhluk individu dan makhluk sosial (Atmanti, 2005), sehingga dapat hidup secara efektif. Melalui pendidikan, peserta didik dibekali dengan berbagai ilmu pengetahuan, mengembangkan nilai-nilai moral dan keterampilannya (Abidin, 2006). Menurut Undang-Undang Sistem Pendidikan Nasional No. 20 Pasal 3 Tahun 2003 (2003) menjelaskan bahwa Pendidikan Nasional bertujuan untuk berkembangnya potensi peserta didik agar menjadi individu yang beriman dan bertakwa kepada Tuhan Yang Maha Esa, berakhlak mulia, sehat, berilmu, cakap, kreatif, mandiri dan menjadi warga negara yang demokratis serta bertanggung jawab.

Oleh karena itu, sekolah sebagai salah satu lembaga pendidikan mempunyai tanggung jawab yang besar dalam mendidik dan menyiapkan para peserta didik agar berhasil dalam proses pendidikan. Sekolah sebagai tempat terjadinya proses belajar dan interaksi sosial (Putri \& Budi, 2003), baik antara peserta didik dan guru, peserta didik dengan peserta didik, peserta didik dengan kelompok, maupun antar kelompok peserta didik yang satu dengan kelompok yang lainnya. Interaksi sosial yang dilakukan peserta didik sebagai salah salah satu bentuk proses hubungan sosial sesuai dengan tugas-tugas perkembangan yang harus dicapai peserta didik. Tercapainya tugas-tugas perkembangan tersebut memberikan arti bahwa telah berkembangnya potensi peserta didik yang optimal. Perkembangan 
sosial remaja dapat diketahui dari kemampuan mereka membina hubungan sosial dengan lingkungan.

Berdasarkan fenomena di SMP N 1 Lubuk Alung dari sejumlah kelas, beberapa peserta didik kelas VIII yang memiliki hubungan sosial terlihat kurang kompak dan masih membentuk kelompok-kelompok dalam bermain dan belajar, rasa saling menghargai dari peserta didik masih kurang, baik dari peserta didik perempuan ataupun laki-laki. Dengan demikian, komunikasi yang terjadi di kelas tersebut kurang harmonis. Data tersebut diperkuat dari hasil sosiometri pada tanggal 9 April 2012 banyak peserta didik yang memiliki masalah dengan hubungan sosial, dimana peserta didik banyak membuat kelompok-kelompok, terisolir, dan saling memilih.

Selanjutnya dari permasalahan hubungan sosial sering tertulis di dalam buku kasus setiap minggu, salah satu contohnya membuat kelompok-kelompok (genggeng) yang ekslusif, sehingga satu kelompok atau geng merasa lebih baik dan lebih hebat dibandingkan dengan kelompok lain. Kelompok tersebut pada akhirnya cenderung memicu adanya konflik antar kelompok, misalnya, karena kelompok atau geng lain adalah out droup maka mereka enggan untuk menolong teman yang berada di luar gengnya, bahkan ada yang berkelahi, dan sampai masuk ke dalam buku kasus.

Berdasarkan fenomena tersebut, maka sangat diperlukan mengidentifikasi masalah-masalah sosial peserta didik kelas VIII melalui layanan konseling kelompok yang telah termasuk dalam program BK di sekolah, dengan tujuan agar peserta didik bisa meningkatkan hubungan sosialnya. Oleh karena itu peneliti tertarik untuk lebih lanjut mengkaji masalah tersebut dengan mengungkapkan pelaksanaan layanan konseling kelompok untuk mengembangkan hubungan sosial peserta didik.

\section{B. METODOLOGI PENELITIAN}

Penelitian ini bersifat field research (penelitian lapangan) dengan menggunakan pendekatan deskriptif kualitatif (Moleong, 2013) yaitu mendeskripsikan secara sistematis faktual dan akurat mengenai fakta-fakta, situasi 
atau kejadian yang berkenaan dengan pelaksanaan bimbingan dan konseling di sekolah. Adapun sumber data penelitian dalam melaksanakan wawancara, observasi dan dokumentasi antara lain koordinator BK, guru BK, guru bidang studi dan wali kelas, dan peserta didik kelas VIII yang terlibat dalam pelaksanaan layanan konseling kelompok di SMPN 1 Lubuk Alung.

\section{HASIL PENELITIAN DAN PEMBAHASAN}

\section{Hubungan Sosial Peserta Didik Kelas VIII dDi SMP Negeri 1 Lubuk}

\section{Alung}

Alisyahbana (dalam Ali dan Asrori, 2004) menjelaskan bahwa hubungan sosial merupakan cara-cara individu bereaksi terhadap orang-orang di sekitarnya dan pengaruh hubungan itu terhadap dirinya. Dengan demikian hubungan sosial menyangkut juga penyesuaian diri terhadap lingkungan, menaati peraturan dan membangun komitmen bersama dalam kelompok atau organisasinya (Kumalasari \& Ahyani, 2012). Selain penyesuaian diri, hubungan sosial juga dapat terbentuk oleh perasaan kebersamaan dan saling menyukai antara satu individu dengan individu lainnya sehingga terjalin hubungan yang akrab.

Sehubungan permasalahan hubungan sosial peserta didik kelas VIII SMPN 1 Lubuk Alung, gambaran permasalahan berorientasi kepada peserta didik yang memiliki masalah hubungan sosial (terisolir) berdasarkan hasil sosiometri, untuk itu informasi diperoleh melalui guru BK dan bidang studi, sebagai berikut:

Wawancara dengan koordinator BK SMP N 1 Lubuk Alung, pada tanggal 16 Desember 2012, menjelaskan:

"Peserta didik yang memiliki masalah hubungan sosial, di dalam kelas peserta didik pada saat belajar cenderung bermalas-malasan, apabila diberikan tugas, dia memaksa temannya untuk membuatkan tugasnya, apabila tidak diberikan, temannya diganggu sampai tugasnya dibuatkan. Jadi saya melihat ketika peserta didik itu berinteraksi dengan teman sekelasnya, teman-temannya itu merasa kurang nyaman dengan kehadiran dirinya. Karena adanya sikap keras yang membuat teman-temannya itu tidak suka". 
Selanjutnya mengenai kondisi peserta didik yang memiliki masalah hubungan sosial, diperoleh keterangan wawancara dengan guru BK SMP N 1 Lubuk Alung, pada tanggal 19 Desember 2012, menjelaskan:

"Di sekolah ini memang banyak terlihat adanya peserta didik yang memiliki masalah dengan hubungan sosial, dimana peserta didik itu sering mengejek, berkelahi, yang pada akhirnya tercatat ke dalam buku kasus oleh guru BK. Dalam belajar mereka sering mengganggu teman-temannya. Sehingga membuat temannya itu jengkel dan tidak mau berteman dengan mereka. Jadi konseling kelompok adalah sebagai sarana pertolongan yang diberikan kepada Peserta didik dalam hal mengembangkan rasa empati serta, membantu peserta didik memecahkan masalahnya, dan juga sarana untuk melatih keberanian dalam mengeluarkan pendapat, sehingga terbentuknya hubungan sosial yang baik dalam kelompok".

Wawancara Guru Bidang Studi SMP N 1 Lubuk Alung, pada tanggal 19 Desember 2012, menjelaskan:

"Pada saat proses belajar mengajar, banyak terlihat peserta didik sering mengganggu teman yang lainnya, terkadang pada saat teman mereka berbicara di dalam kelas mereka mencemooh dan suka menertawakan teman-temannya. apabila ditegur mereka diam saja namun beberapa lama kemudian kembali lagi, hal itu diulang kembali. dan apabila membuat tugas mereka banyak berjalan-jalan dan mendekati teman yang sedang asyik mengerjakan tugas dan kemudian mengganggunya, dan tidak sedikit juga yang sering remedi dalam setiap ulangan harian ataupun ujian Mid dan akhir semester dan itu bukan hanya pada satu mata pelajaran tapi beberapa mata pelajaran. Kemudian kehadiran mereka sering dipertanyakan karna sering alfa ataupun cabut pada saat jam pelajaran".

Wawancara dengan salah satu satu satu guru wali kelas dari kelas VIII SMP

N 1 Lubuk Alung, pada tanggal 18 Desember 2012, menjelaskan:

"Permasalahan yang banyak terjadi oleh peserta didik banyak berpengaruh dengan hasil belajarnya, dikarenakan ada yang sering alfa, ataupun cabut, ada yang bermasalah dengan guru mata pelajaran dalam proses belajar mengajar, ataupun karna perkelahian dengan teman yang lain pada saat pelajaran berlangsung, ada juga yang saling mengejek yang pada akhirnya terjadi perkelahian ".

Melalui pernyataan guru BK, mata pelajaran dan wali kelas, dapat disimpulkan bahwa peserta didik yang memiliki masalah dalam hubungan sosial menjadikan peserta didik mengalami kesulitan berinteraksi dengan temantemannya dalam belajar, selain itu dalam buku kasus adaanya peserta didik yang 
beberapa kali bertengkar dikarenakan hal sepele atau ia memulai perkelahian. Sehubungan dengan perkelahian dan hubungan sosial peserta didik berdasarkan sosiometri, maka diperoleh keterangan bahwa:

Wawancara dengan salah satu satu peserta didik yang terisolir kelas VIII.8 SMPN 1 Lubuk Alung, pada tanggal 06 Desember 2012, menjelaskan:

"Saya senang mengganggu teman-teman tersebut, ketika saya meminta tolong mereka tidak mau membantu, tidak mau menolong, dalam belajar tidak mau menujukkan pelajaran terhadap saya, mentang-mentang mereka pintar mereka menjadi pelit dan tidak mau berbagi, sombong, ada juga yang sok kecantikan. Saya tidak suka melihat orang seperti itu, saya tidak memulai pertengkaran, saya cuma melakukan apa yang tidak saya sukai pada dia biar mereka tahu ".

Wawancara dengan salah satu peserta didik kelas VIII.8 SMP N 1 Lubuk Alung, pada tanggal 06 Desember 2012, menjelaskan:

"Saya sering tidak nyaman dan kesal terhadap teman saya yang suka mengganggu, terkadang saya hanya diam saja tapi tetap diganggunya, apabila ada tugas dari guru dia hanya meminta dibuatkan saja, tanpa berusaha sendiri dan itu sering terjadi, saya tidak senang diperlakukan seperti itu".

Wawancara dengan salah satu peserta didik yang terisolir kelas VIII.7 SMPN 1 Lubuk Alung, pada tanggal 06 Desember 2012, menjelaskan:

"Saya sering dihina soal fisik saya, terkadang saya suka dikucilkan karna fisik saya, dan dia sering mencemoohkan saya, apabila saya melawan, saya dikucilkan, kalau saya diam saja saya terus diganggunya" .

Dari pernyataan peserta didik di atas terlihat bahwa ada beberapa peserta didik yang sering mengganggu teman-temannya yang mengakibatkan temantemannya itu tidak senang, sampai pada akhirnya mereka berkelahi. Selain itu, reaksi teman-temannya ada yang diam saja karena perbuatannya dan terkadang ada yang membantah bahkan tidak menerima perlakuaannya itu. Hal tersebut berdasarkan observasi yang mana peserta didik bermasalah sering dihindari oleh teman-temannya yang lain, mereka sering diacuhkan saja, hubungan sosial mereka menbentuk geng tersendiri namun tidak jarang juga menimbulkan perkelahian karena bentuk interaksi yang saling mencemooh, menghina dan lain sebagainya.

Dalam suatu hubungan sosial, individu dituntut untuk siap menghadapi berbagai resiko, karena dalam suatu hubungan di samping individu berusaha untuk memenuhi keinginan dan harapan diri, individu dituntut untuk mau 
membantu orang lain memenuhi keinginan dan harapannya, yang terkadang kurang sesuai dengan kepribadian individu tersebut (Soemanto, 2014). Individu yang kurang bisa menerima atau belum siap menghadapi resiko dalam usaha untuk menyesuaikan diri dengan orang lain seperti bersikap seperti apa yang disukai orang lain, maka dia akan menarik dirinya dari lingkungan sosialnya tersebut (Hidayati, 2016). Sikap ini dapat mengirimkan pesan bahwa individu tersebut tidak menyukai lingkungannya dan akibatnya lingkungan meninggalkannya. Dengan demikian individu tersebut akan menciptakan dunianya sendiri sebagai kompensasi dari perasaan sepi dan terasing.

\section{Penyebab Masalah Hubungan Sosial Peserta Didik Kelas VIII di SMP Negeri 1 Lubuk Alung}

Pada masa remaja tingkah laku dan minat yang dibawa dari masa kanakkanak cenderung berubah dan berkurang digantikan oleh tingkah laku dan minat baru dalam bertingkah laku sosial. Hurlock (1990) mengemukakan bahwa dalam masa remaja, berdasarkan pengalaman, kebanyakan remaja memperoleh nilai yang berbeda dan lebih matang dari sebelumnya dalam bertingkah laku sosial. Adapun tingkah laku sosial yang diperoleh secara berbeda dapat dipengaruhi beberapa faktor, berdasarkan berdasarkan wawancara dengan guru BK tentang peserta didik yang memiliki masalah hubungan sosial pada tanggal 15 Januari 2013, diperoleh keterangan:

"Sebenarnya banyak faktor yang mempengaruhi tentang masalah hubungan sosial peserta didik di sekolah ini, misalnya keadaan ekonomi keluarga, pengaruh teman sebaya dan pola asuh orang tua yang merupakan faktor utama terjadinya masalah hubungan sosial. Kita tahu bahwa hubungan sosial pada anak awalnya terbentuk dari lingkungan keluarga mereka sendiri ".

Senada dengan pernyataan di atas wawancara dengan koordinator BK pada tanggal 16 Januari 2013, beliau mengatakan:

"Mengenai Hubungan sosial peserta didik sebenarnya banyak faktor yang mempengaruhinya, dimana peserta didik di sini sering membeda-bedakan teman dikarenakan teman-teman yang lain dari keluarga yang kurang mampu. Ada juga dari keluarga yang kaya (dalam artian orang tua yang sibuk dengan urusan kerja sehingga kasih sayang orang tua tidak sepenuhnya 
didapatkannya). Ada juga karena pola asuh orang tua yang otoriter sehingga cara bergaul dengan teman-temannya itu dibawakan seperti apa yang diperlakukan orang tuanya kepada dia. Karena hal itulah banyak terjadi peserta didik yang mengalami masalah dengan hubungan sosialnya ".

Wawancara dengan guru bidang studi pada tanggal 16 Januari 2013, beliau menjelaskan:

"Di dalam kelas hubungan sosial peserta didik memang banyak yang bermasalah. Dimana di kelas ada beberapa peserta didik yang bersosialisasi berkelompok-klompok. Ada yang pintar sama yang pintar, yang kurang pintar dengan sesamanya, anak yang ekonominya lebih sama dengan anak yang ekonominya lebih dan bahkan juga ada yang sendiri karena ekonomi kelurga yang kurang mampu. Hal ini banyak disebabkan oleh faktor keluarga, keadaan ekonomi keluarga yang kurang dan juga disebabkan oleh pola asuh orang tua yang keras yang menyebabkan ia jga berprilaku keras kepada teman-temannya dan membeda-bedakan teman-temannya".

Kemudian wawancara salah satu peserta didik kelas VIII.8 pada tanggal 14 Desember 2012, menjelaskan:

"Saya tidak suka berteman dengan dia karena dia pelit sekali, apabila pergi belanja dia tidak mau membayar sendiri. Alasannya tidak punya uang. Dia suka menyuruh-nyuruh saya melakukan sesuatu untuk kepentingan dia sendiri. Kalau tidak dituruti dia sering marah-marah. Dalam berteman ia suka memilih-milih".

Wawancara dengan salah satu peserta didik kelas VIII. 7 pada tanggal 14 Desember 2012 menjelaskan:

"Saya tidak suka berteman dengan dia, dia sering membentak-bentak temannya, sering mencemooh, sering membuat temannya menangis, sering menghasut teman-teman yang lain yang pada akhirnya teman-temannya itu berkelahi, dan juga kebiasaan buruknya itu karena ikut-ikutan teman, temannya membentak teman yang lain dan ia juga mencoba membentak dalam artian sok pemberani atau merasa paling memiliki segalanya”.

Berdasarkan wawancara di atas disimpulkan bahwa faktor yang menyebabkan masalah hubungan sosial peserta didik kelas VIII SMPN 1 Lubuk Alung yaitunya faktor ekonomi, pola asuh orang tua dan pengaruh teman sebaya. Dari faktor ekonomi peserta didik memilih-milih teman dalam bersosialisasi, faktor pola asuh ada peserta didik yang keras kepada teman-temannya, dan lain sebagainya.

Senada dengan hal tersebut, Mudjiran dkk (2001) mengemukakan ada tiga faktor yang mempengaruhi tingkah laku sosial remaja, yaitu orang tua, sekolah 
dan teman sebaya. Ali dan Asrori (2004) juga menjelaskan bahwa hubungan sosial ini mula-mula dimulai dari lingkungan rumah sendiri, kemudian mulai berkembang ke lingkungan sekolah dan dilanjutkan kepada lingkungan yang lebih luas, yaitu teman sebaya. Selain orang tua dan teman sebaya, beberapa peserta didik yang memilih-milih teman, dan berkelompok hanya dengan anak yang memiliki ekonomi tinggi menjadi salah satu faktor masalah hubungan sosial, sehingga dengan hal tersebut maka antar mereka terjadi kesalahpahaman yang akhirnya dapat menimbulkan perkelahian antar sesama mereka (seperti: mengolok-olok) dan lain sebagainya.

\section{Konseling Kelompok untuk Mengembangkan Hubungan Sosial Peserta Didik Kelas VIII di SMP Negeri 1 Lubuk Alung}

Layanan konseling kelompok yaitu layanan bimbingan dan konseling yang memungkinkan peserta didik memperoleh kesempatan untuk pembahasan dan pengentasan permasalahan yang dialaminya melalui dinamika kelompok (Abidin, 2009). Sedangkan dinamika kelompok menurut Sukardi (2002) ialah suasana yang hidup, yang berdenyut, yang bergerak, yang dsitandai dengan adanya interaksi antar sesama anggota kelompok. Berdasarkan hasil dari layanan konseling kelompok di SMPN 1 Lubuk Alung, diperoleh keterangan dari beberapa orang guru BK, tentang usaha yang dilakukan untuk masalah hubungan sosial. Hasil wawancara dengan guru BK pada tanggal 15 Januari 2013, menjelaskan:

"Dalam mengembangkan hubungan sosial peserta didik bisa dilaksanakan dengan pelaksanaan layanan konseling kelompok. Dimana peserta didik disini bisa memiliki hubungan yang baik karena dibentuk dengan adanya dinamika kelompok, dan juga mereka merasa senang dengan kegiatan tersebut. Dengan konseling kelompok mereka tertarik mengeluarkan pendapat dalam kelompok kecil. Selain itu mereka juga merasa ada kedekatan dengan teman sekelas dan dapat bertukar pikiran dengan dengan teman-teman".

Selanjutnya wawancara dengan guru BK pada tanggal 16 Januari 2013, beliau menyatakan bahwa:

"Ada beberapa peserta didik yang tidak mau bekerja sama denga temantemannya baik itu di luar kelas maupun di dalam kelas. Peserta didik tersebut lebih suka menyendiri karna ia beranggapan, temannya itu tidak ada yang bisa dipercaya, jadi dengan adanya konseling kelompok peserta didik tersebut bisa 
merubah cara berfikirnya, hal ini terlihat dari kesungguhan siswa tersebut dalam mengungkapkan masalahnya ketika pelaksanaan konseling kelompok sehingga hubungan sosialnya lebih tercipta dengan baik."

Koordinator BK SMP Negeri 1 Lubuk Alung pada tanggal 16 Februari juga mengungkapkan bahwa:

"Kita sama-sama tahu bahwa peserta didik SMP merupakan masa transisi dari anak-anak ke remaja awal, sebenarnya di SMP N 1 Lubuk Alung ini memiliki berbagai macam masalah tentang hubungan sosial di antaranya, kurangnya rasa menghargai antar sesamanya, suka memilih-milih teman bahkan sampai berkelahi. Namun setelah diadakan konseling kelompok ini dengan beberapa tahap yang harus dilalui terlihat adanya perubahan pada peserta didik tersebut, hal ini dibuktikan ketika melaksanakan konseling kelompok peserta didik itu begitu terlihat rasa saling menghargai satu sama lainnya sudah tinggi, begitu juga dengan kekompakannya".

Setelah itu wawancara dengan guru mata pelajaran pada tanggal 15 Februari 2013, mengungkapkan bahwa:

"Memang telah terlihat sekali perubahan yang terjadi pada peserta didik setelah adanya konseling kelompok. Diman peserta didik pada awalnya suka mengganggu, suka usil, sekarang telah berubah menjadi peserta didik yang memiliki sikap yang baik, tidak ada lagi mengejek teman, mengganggu teman, bahkan sampai berkelahi dalam kelas. Dari hasil proses belajarnya juga terlihat bahwa peserta didik tersebut sudah memiliki hasil belajar yang bagus. Dimana peserta didik ini sudah bisa membuat kelompok belajar sendiri. Jadi tidak ada lagi kelompok geng-geng yang membuat perpecahan di antara peserta didik".

Berdasarkan pernyataan di atas, dapat dimaknai konseling kelompok yang diadakan sangat membantu bagi peserta didik dalam mengembangkan hubungan sosialnya, baik di lingkungan sekolah, keluarga, rumah maupun masyarakat. Karena rasa saling menghargai dan menghormatinya telah bisa diciptakannya. Tidak muncul lagi rasa memilih-milih teman dalam bersosialisasi, semuanya telah dianggap sama, sehingga dengan itu terciptalah hubungan sosial yang baik antar mereka. Hal ini juga disampaikan salah satu peserta didik yang terisolir kelas VIII.8 pada tanggal 09 Februari 2013 yang mengikuti kegiatan konseling kelompok:

"Sebenarnya sebelum pelaksanaan konseling kelompok ini, kami tidak berani untuk mengungkapkan pendapat di depan umum, jangankan mengemukakan pendapat, teman saja mengemukakan pendapatnya kami pun 
menertawakannya. Namun, setelah adanya konseling kelompok ini hal itu bisa berubah karna kami sudah bisa saling menghargai satu sama lainnya, jika ada teman yang berpendapat kami pun mendengarkan pendapatnya, bahkan kami pun berani mengeluarkan pendapat".

Hal ini senada dengan ungkapan salah satu peserta didik kelas VIII.7 pada tanggal 09 Februari 2013, mengungkapkan bahwa:

"Setelah adanya konseling kelompok ini saya lebih bisa memberikan kepercayaan kepada teman saya, saya sudah berani mengemukakan permasalahan saya di depan teman-teman, padahal sebelumnya hal itu belum pernah saya lakukan, karna saya fikir teman-teman saya tidak bisa dipercaya, dan karna saya juga sering mendapat ejekan ataupun dikucilkan, ternyata setelah dilakukan konseling kelompok saya sudah bisa menanggapi dengan baik ejekan teman, karena fisik saya yang kurang, serta sudah belajar untuk memaafkan, karena sudah ada rasa saling menghargai satu sama lain dan setelah adanya konseling kelompok, teman-teman juga sudah bisa untuk dipercayai terbukti, sampai saat sekarang ini teman saya menyimpan masalahmasalah yang saya kemukakan ketika konseling kelompok (tidak diketahui oleh kelompok lain) “.

Kemudian wawancara dengan peserta didik kelas VIII.8 pada tanggal 16

Februari 2013 yang memiliki masalah hubungan sosial yang mengikuti kegiatan konseling kelompok, menjelaskan:

"Setelah mengadakan konseling kelompok ini ternyata saya menyadari apa yang telah saya perbuat dan tindakan yang saya lakukan terhadap temanteman adalah hal yang membuat saya tidak disukai, saya selama ini tidak mengetahui bagaimana mereka terhadap saya, melalui konseling kelompok ini saya menyadari pentingnya untuk saling menjaga hubungan yang baik dengan teman-teman, sekarang saya ingin berusaha untuk tidak lagi berbuat yang tidak disukai oleh teman-teman saya".

Melalui perubahan yang terjadi pada peserta didik setelah diadakan konseling kelompok, maka peserta didik sudah bisa saling menghargai satu sama lainnya, bersosialisasi dengan baik dalam artian tidak memilih-milih teman lagi, saling membantu antar sesama yang dimaknai rasa empati yang ada pada diri peserta didik sudah berkembang. Hal tersebut senada dengan makna konseling kelompok merupakan suatu proses antar pribadi yang dinamis, terpusat pada pikiran dan perilaku yang disadari, dibina, dalam suatu kelompok kecil mengungkapkan diri kepada sesama anggota dan konselor, dimana komunikasi antar pribadi tersebut dapat dimanfaatkan untuk meningkatkan pemahaman dan penerimaan diri 
terhadap nilai-nilai kehidupan dan segala tujuan hidup serta untuk belajar perilaku tertentu ke arah yang lebih baik (Winkel dan Hastuti, 2008). Dengan demikian, konseling kelompok dapat dimaknai sebagai upaya BK atau konselor membantu memecahkan masalah-masalah pribadi yang dialami oleh masing-masing anggota kelompok melalui kegiatan kelompok agar tercapai perkembangan yang optimal, dan proses belajar pun sudah terlihat menjadi lebih baik dikarenakan hubungan sosial yang lebih baik.

\section{SIMPULAN}

Berdasarkan temuan dan pembahasan hasil penelitian, maka dapat dikemukakan bahwa konseling kelompok untuk mengembangkan hubungan sosial peserta didik kelas VIII di SMP Negeri 1 Lubuk Alung melalui empat tahapan konseling kelompok yaitu tahap pembentukan, tahap peralihan, tahap kegiatan, dan tahap pengakhiran, serta berdasarkan tujuan konseling kelompok yaitu untuk mengentaskan permasalahan yang dirasakan oleh anggota kelompok dan juga mengembangkan rasa empati yang ada pada diri anggota kelompok, terlihat perubahan yang sangat berarti mengenai hubungan sosial peserta didik yang berdasarkan observasi serta wawancara yang telah dilakukan. 


\section{DAFTAR PUSTAKA}

Abidin, Z. (2006). Motivasi dalam Strategi Pembelajaran dengan Pendekatan “Arcs”Suhuf, XVIII (2), 143-155.

Abidin, Z. (2009). Optimalisasi Konseling Individu dan Kelompok untuk Keberhasilan Siswa. Insania, 14 (1), 1-12.

Ali, M dan Asrori, M. (2004). Psikologi Remaja. Jakarta: Bina Aksara.

Atmanti, D. H. (2005). Investasi Sumber Daya Manusia melalui Pendidikan. Jurnal Dinamika Pembangunan (JDP), 2(1), 30-39.

Hurlock, E. B. (1990). Psikologi Perkembangan: Suatu Pendekatan Sepanjang Rentang Kehidupan. Jakarta: Erlangga.

Hidayati, N. W. (2016). Hubungan Harga Diri dan Konformitas Teman Sebaya dengan Kenakalan Remaja. Jurnal Penelitian Pendidikan Indonesia (JPPI), 1(2), 2477-3921.

Sukardi, D. K. (2002). Pengantar Pelaksanaan Bimbingan dan Konseling. Jakarta: Rineka Cipta.

Kumalasari, F., \& Ahyani, L. N. (2012). Hubungan Antara Dukungan Sosial dengan Penyesuaian Diri Remaja di Panti Asuhan. Jurnal Psikologi Pitutur, 1(1), 21-31.

Moleong, J.Lexy. (2013). Metode Penelitian Kualitatif. Bandung: Remaja Rosdakarya.

Mudjiran, dkk. (2001). Perkembangan Peserta Didik. Padang: Dirjen Pendidikan Tinggi.

Putri, M. O., \& Budi, A. (2003). Hubungan Antara Dukungan Sosial Ayah dengan Penyesuaian Sosial pada Remaja Laki-Laki. Jurnal Psikologi, (1), 23-35.

Santrock, John W. (2003). Perkembangan Remaja (Edisi Ke-Enam). Jakarta: Erlangga.

Soemanto, R. . (2014). Pengertian dan Ruang Lingkup Sosiologi Keluarga, 145.(Online)

UU No. 20 SISDIKNAS Tahun 2003. Jakarta: Departemen Agama RI.

Winkel dan Hastuti. (2008). Bimbingan dan Konseling Kelompok. Jakarta: Rineka Cipta. 